\title{
Solanum nigrum grown in contaminated soil: Effect of arbuscular mycorrhizal fungi on zinc accumulation and histolocalisation
}

\author{
Ana P.G.C. Marques ${ }^{\text {a }}$, Rui S. Oliveira ${ }^{a}$, Kalina A. Samardjieva ${ }^{\text {b }}$, José Pissarra ${ }^{\text {c }}$, \\ António O.S.S. Rangel ${ }^{\text {a }}$, Paula M.L. Castro ${ }^{\text {a,* }}$ \\ ${ }^{a}$ Escola Superior de Biotecnologia, Universidade Católica Portuguesa, Rua Dr. António Bernardino de Almeida, 4200-072 Porto, Portugal \\ ${ }^{\mathrm{b}}$ Instituto de Biologia Molecular e Celular, Universidade do Porto, Rua do Campo Alegre 823, 4150-180 Porto, Portugal \\ ${ }^{\mathrm{c}}$ Faculdade de Ciências da Universidade do Porto, Departamento de Botânica, Rua do Campo Alegre, 1191, 4150-181 Porto, Portugal
}

Zn accumulation by $S$. nigrum is enhanced by AMF and the metal storage in the tissues at the root level occurs mainly in the cell walls and in the intercellular spaces.

\begin{abstract}
$\mathrm{Zn}$ tissue accumulation in Solanum nigrum grown in a non-contaminated and a naturally contaminated $\mathrm{Zn}$ matrix and the effect of inoculation with different arbuscular mycorrhizal fungi (AMF) on metal uptake were assessed. S. nigrum grown in the contaminated soil always presented higher $\mathrm{Zn}$ accumulation in the tissues, accumulating up to $1622 \mathrm{mg} \mathrm{Zn} \mathrm{kg} \mathrm{g}^{-1}$. The presence of both Glomus claroideum and Glomus intraradices enhanced the uptake and accumulation of $\mathrm{Zn}$ by S. nigrum (up to 83 and $49 \%$ higher Zn accumulation, respectively). The main deposits of the metal were found in the intercellular spaces and in the cell walls of the root tissues, as revealed by autometallography, with the inoculation with different AMF species causing no differences in the location of $\mathrm{Zn}$ accumulation. These findings indicate that $S$. nigrum inoculated with selected heavy metal tolerant AMF presents extracting and accumulating capacities, constituting a potentially suitable remediation method for $\mathrm{Zn}$ polluted soils.
\end{abstract}

Keywords: Solanum nigrum; Arbuscular mycorrhizal fungi; Zn; Phytoremediation; Autometallography

\section{Introduction}

The contamination of nature compartments by heavy metals has become a serious environmental problem. The worldwide release of heavy metals has reached $1,350,000$ tons $\mathrm{Zn}$ in 2002 (Singh et al., 2003). The menace posed by toxic metals should be solved, due to environmental and human health safety reasons. Due to the high cost of conventional clean-up technologies, there is an increasing interest in the remediation

\footnotetext{
* Corresponding author. Tel.: +351 2255800 59; fax: +351 225090351 E-mail addresses: amarques@mail.esb.ucp.pt (A.P.G.C. Marques), rsoliveira@mail.esb.ucp.pt (R.S. Oliveira), kas@ibmc.up.pt (K.A. Samardjieva), jpissarr@fc.up.pt (J. Pissarra), arangel@esb.ucp.pt (A.O.S.S. Rangel), plcastro@esb.ucp.pt (P.M.L. Castro).
}

of contaminated sites using biological environmental friendly techniques. One such method is phytoremediation-the use of plants to remove, degrade or immobilize contaminants. Over 400 hyperaccumulator species-plants that accumulate up to $1 \%$ of the contaminant in the aboveground harvestable dry tissues (McGrath and Zhao, 2003) - have been reported, but generally these species bring up the problem of low biomass yield and growth rate (Baker et al., 2000). For this, fast growing, high biomass species colonising contaminated soils may present themselves as potential plants for the implementation of phytoremediation strategies.

Solanum nigrum L. (black nightshade) is a pioneer species growing in a polluted site in northern Portugal. This industrialised area presents levels of $\mathrm{Zn}$ that remain above the limits established by EC Directive 86/278/EC (Atkins, 1999). 
Collected plants at the site have been shown to accumulate up to $1130 \mathrm{mg} \mathrm{Zn} \mathrm{kg}^{-1}$ tissue (Marques et al., 2003). Solanum nigrum was also found to proliferate in other metal polluted sites; Khan et al. (1998) found S. nigrum growing in a steelworks waste site in Australia, accumulating up to $82 \mathrm{mg} \mathrm{Zn}$, $15 \mathrm{mg} \mathrm{Pb}, 3 \mathrm{mg} \mathrm{Cu}$ and $17 \mathrm{mg} \mathrm{Cd}$ per kg dry tissue. Remediation experiments using $S$. nigrum are scarce. Macek et al. (1994) studied Cd accumulation by S. nigrum hairy-root cultures and reported metal accumulation up to $24 \mathrm{mg} \mathrm{Cd} \mathrm{kg}^{-1}$ dry plant tissue. $S$. nigrum has also been shown to accumulate up to $3800 \mathrm{mg} \mathrm{Zn} \mathrm{kg}^{-1}$ dry tissue in the roots, with no visible toxicity signs, when grown in sand spiked with $100 \mathrm{mg} \mathrm{Zn}$ $\mathrm{kg}^{-1}$ (Marques et al., in press).

Arbuscular mycorrhizal fungi (AMF) are important root symbionts that may play a central role in a phytoremediation process (Merharg and Cairney, 2000). While plants provide important compounds for AMF survival, these fungi expand the contact surface between plants and soil, contributing to an enhanced plant uptake of macronutrients (Li et al., 1991) and micronutrients such as Zn (Bürkert and Robson, 1994). Although $\mathrm{Zn}$ is a micronutrient for plants, at higher concentrations it may become toxic (Borkert et al., 1998; Ebbs and Kochian, 1997). The contribution of AMF to plant adaptation in highly Zn contaminated sites varies. Huang et al. (2002) reported an exclusion strategy, showing lower $\mathrm{Zn}$ accumulation by AMF colonised Zea mays, while Jamal et al. (2002) reported an accentuation of $\mathrm{Zn}$ and $\mathrm{Ni}$ uptake in Glycine max and Lens culinaris.

The effect of metal pollution in plants growing in an artificially contaminated matrix may not be the same as for the individuals growing in a naturally contaminated soil, as differences in the biological availability of the metal, exposure to metal mixtures and adaptation to metal stress may occur (Lock et al., 2003). The use of naturally contaminated soils instead of spiked soils can shorten the differences between lab and field experiments in the description of natural processes. It has been show that data resulting from such studies are in line with those obtained from field conditions (Bernhard et al., 2005).

The knowledge of the metal distribution in cell compartments is important for understanding the tolerance mechanisms in plant species. Metal accumulation in plant roots may reflect metal merely absorbed onto the root surface rather than within the root tissue (Weis and Weis, 2004). Studies on the histolocalisation of heavy metals in plants are rare (Heumann, 2002).

The aim of this study was to assess the influence of AMF on plant biomass production and $\mathrm{Zn}$ uptake and accumulation in plants growing in a naturally contaminated soil, and to determine the location of the accumulated $\mathrm{Zn}$ in plant tissues by autometallography.

\section{Materials and methods}

\section{Site description, soil sampling and sand preparation}

The soil used in this study was collected at a site located in Northern Portugal, Esteiro de Estarreja. It is a small and almost stagnated watercourse, contaminated with the discharges of an adjacent wastewater conduct originating from the industrial complex that surrounds the area. The solid residues produced in the chemical complex, essentially contaminated with zinc, lead, arsenic, mercury, vanadium, and fluorites, were also discharged nearby the stream. Profiting from the high permeability of the site, the percolates proceeding from this improvised residue deposit infiltrated into the soil of the area These emissions no longer occur, but high levels of metal contamination, especially Zn, are present (Atkins, 1999; Oliveira et al., 2001). The banks of the stream, ca. $2 \mathrm{~m}$ wide, are periodically flooded, from late October to late February, and the ditch of the stream remains almost dry during the remaining months. According to Atkins (1999), the metal contamination throughout the banks and between banks is very heterogeneous, with the area near the former exit of the wastewaters being the most polluted one. Soil was collected randomly from the banks of the contaminated stream, to a $20 \mathrm{~cm}$ depth, in the dry season.

Sand $(\mathrm{pH} 7,0.5-1.0 \mathrm{~mm}, 0.45 \%$ loss on ignition, acquired from Areipor, Bucelas, Portugal) is an inert substrate, with only vestigial levels of $\mathrm{Zn}$, and was thus used as a control matrix. Sand was immersed in $0.1 \mathrm{M} \mathrm{HCl}$ for $24 \mathrm{~h}$ and rinsed with deionised water.

Sand and the collected soil were sterilised at $120^{\circ} \mathrm{C}$ for $70 \mathrm{~min}$ in two consecutive days and dried in a drying oven at $40{ }^{\circ} \mathrm{C}$ for 4 days.

\section{Preparation of mycorrhizal inocula}

The four isolates of AMF used in this study have been isolated from heavy metal contaminated soils in central Europe and are in the AMF collection of the Department of Mycorrhizal Symbioses from the Institute of Botany, Academy of Sciences of the Czech Republic. Each of the four mycorrhizal fungi isolates was individually grown in zeolite (clinoptilolite $1.0-2.5 \mathrm{~mm}$, Chemko, Slovakia) for 12 months prior to the beginning of the experiment in multispore pot cultures with both Zea mays $\mathrm{L}$. and Trifolium pratense $\mathrm{L}$. as host plants, under controlled growth room conditions $(12 \mathrm{~h}$ photoperiod, $450 \mu \mathrm{mol} \mathrm{m} \mathrm{m}^{-2} \mathrm{~s}^{-1}$ photosynthetically active radiation, $18-38^{\circ} \mathrm{C}$ temperature range, $16-71 \%$ relative humidity range). An inoculum suspension of each isolate was prepared by wet sieving $(710 \mathrm{~mm}) 450 \mathrm{~cm}^{3}$ of zeolite from pot cultures with deionised water to a final volume of $150 \mathrm{ml}$. Each pot of the mycorrhizal treatments received $10 \mathrm{ml}$ of the inoculum suspension containing colonised root fragments, hyphae and spores. The suspension was pipetted at $2 \mathrm{~cm}$ below the sand matrix surface. Plants inoculated with the mixture of the four AMF received an inoculum suspension composed of equal parts of the four inocula. Pots from the control treatments received the same volume of the inoculum suspension autoclaved twice $\left(121^{\circ} \mathrm{C}\right.$ for $\left.25 \mathrm{~min}\right)$.

\section{Experimental design}

The experiment was a factorial design with two matrix $\mathrm{Zn}$ levels (sand, considered as the control, and contaminated soil) and six mycorrhizal fungi treatments (no AMF, Glomus sp. BEG140, Glomus claroideum, Glomus mosseae, Glomus intraradices and a mixture of all the AMF isolates). Each treatment was replicated six times.

Solanum nigrum seeds were surface sterilised with $0.5 \%$ (v/v) $\mathrm{NaOCl}$ for $10 \mathrm{~min}$ and were subsequently washed with sterilised deionised water. Seeds were then germinated in plastic pots with about $500 \mathrm{~g}$ sterilised soil or sand. Each pot received 15 seeds. Pots were randomised in the greenhouse, a process that was repeated every 3 weeks. After sowing, seedlings were reduced to three per pot. The plants were maintained in a controlled growth room (12 $\mathrm{h}$ photoperiod, $450 \mu \mathrm{mol} \mathrm{m} \mathrm{m}^{-2} \mathrm{~s}^{-1}$ photosynthetically active radiation, $18-38^{\circ} \mathrm{C}$ temperature range, $16-71 \%$ relative humidity range), were watered daily. Plants growing in the sand matrix were supplemented with modified Hoagland solution containing 1/4 of the original P content and free of $\mathrm{Zn}$ (Hoagland and Arnon, 1950) once a week.

\section{Plants sampling}

The harvesting was made 28 weeks after seedling. Plant roots were washed free of sand or soil with deionised water. For assessing AMF colonisation, a subsample of fresh fine roots was collected from the plants sampled at 
each selected spot. Roots, stems and leaves were separated, oven dried at $70{ }^{\circ} \mathrm{C}$ for 2 days, after which biomass was determined by weighing the dried plant material.

\section{Mycorrhizal colonisation}

To assess AMF colonisation, the fresh fine root sub-samples were cut into approximately $1 \mathrm{~cm}$ pieces, heated in a pressure pan at $120^{\circ} \mathrm{C}$ in $10 \% \mathrm{KOH}$ and stained using an adaptation of the Phillips and Hayman (1970) protocol including a longer incubation in $2 \% \mathrm{HCl}$ (Oliveira et al., 2001). Stained root samples were examined microscopically to assess the percentage of mycorrhizal colonisation using the grid-line intersect method (Giovannetti and Mosse, 1980).

\section{$\mathrm{Zn}$ accumulation in the plant}

For $\mathrm{Zn}$ content analysis, dried roots, stems and leaves were grinded and sieved to $<1 \mathrm{~mm}$. The resulting samples were then digested at high temperature (up to $205^{\circ} \mathrm{C}$ ) with a mixture of concentrated nitric, perchloric and sulphuric acids (40:4:1). Zn content was determined using FA-AAS of the digests (Wallinga et al., 1989). BCR (Community Bureau of Reference) reference sample CRM 279 (sea lettuce) was analysed using the above-described total $\mathrm{Zn}$ determination analytical method. The value obtained by FA-AAS $\left(52.1 \pm 1.1 \mathrm{mg} \mathrm{Zn} \mathrm{kg}^{-1}\right.$ sample) confirmed the accuracy and precision of the method by comparison with the certified value $\left(51.3 \pm 1.2 \mathrm{mg} \mathrm{Zn} \mathrm{kg}^{-1}\right.$ sample).

\section{Autometallography}

Autometallography was performed on small pieces of roots according to Heumann (2002), except that phosphate buffer was substituted for piperazine-1,4-bis(2-ethanesulfonic acid) (PIPES) buffer (Salema and Brandão, 1973 ) and using $\mathrm{Na}_{2} \mathrm{~S}$ as $\mathrm{S}$ donor (Danscher and Montagnese, 1994). The samples without osmium tetroxide treatment were embedded in EPON. Ultrathin sections were prepared using a glass or diamond knife on an ultramicrotome (Supernova Reichert), collected on nickel grids and contrasted with uranil acetate and lead citrate. The sections were observed under a transmission electron microscope (Zeiss EM 10C). Semi-thin sections for light microscopy were stained with saphranine and photographed on an Optiphot2 microscope.

\section{Soil analysis}

Soil samples were oven dried at $40{ }^{\circ} \mathrm{C}$ for $48 \mathrm{~h}$ and passed through a $2 \mathrm{~mm}$ sieve. The soil $\mathrm{pH}$ was measured using a 1:2.5 (w/v) soil water ratio. Water content was determined by drying pre-oven dried $\left(40{ }^{\circ} \mathrm{C}\right)$ soil at $105^{\circ} \mathrm{C}$ until constant mass was achieved. Organic matter content was determined by loss on ignition. Samples for total phosphorous and nitrogen were digested at high temperatures (up to $330^{\circ} \mathrm{C}$ ) with a selenium and salicylic and sulphuric acids mixture and determined by colorimetry. Soil samples were digested at high temperatures (up to $140^{\circ} \mathrm{C}$ ) with concentrated nitric and hydrochloric acids (1:1), for total $\mathrm{Zn}$ determination. All previous methods were based on Houba et al. (1995). The water (De Koe, 1994), exchangeable (Thomas, 1982) and available (Thomas, 1982) $\mathrm{Zn}$ fractions were determined using, respectively, 1:5 soil water (De Koe, 1994), 1:5 soil $1 \mathrm{M} \mathrm{NH}_{4}$-Ac (De Koe, 1994), and 1:10 soil 0.05 M EDTA (Houba et al., 1995) ratios (w/v). The resulting solutions were incubated for $2 \mathrm{~h}$ at $20^{\circ} \mathrm{C}$, after which they were filtrated through a $0.45 \mu \mathrm{m}$ cellulose acetate filter. The $\mathrm{Zn}$ content of the resulting digests and extracts were determined using flame atomic absorption spectroscopy (FA-AAS) in an Unicam 960 spectrophotometer (Houba et al., 1995). BCR (Community Bureau of Reference) reference sample CRM 141 $\mathrm{R}$ (calcareous loam soil) was analysed through the above-referred total $\mathrm{Zn}$ determination analytical method. The value obtained by FA-AAS $(284 \pm 1 \mathrm{mg}$ $\mathrm{Zn} \mathrm{kg}^{-1}$ sample) confirmed the accuracy and precision of the method by comparison with the certified value ( $283 \pm 5 \mathrm{mg} \mathrm{Zn} \mathrm{kg}^{-1}$ sample).

\section{Statistical analysis}

Statistical analysis was performed using the SPSS software program (SPSS Inc., Chicago, IL Version 12.0). The data were analysed by one-way analysis of variance (ANOVA). To detect the statistical significance of differences $(P<0.05)$ between means, the Tukey test was performed.

\section{Chemicals}

The chemicals used were analytical-grade and were obtained from Sigma (Trypan Blue colorant, PIPES, citric acid, arabic gum and $\mathrm{AgNO}_{3}$ ), AGA (ethanol), TAAB (glutaraldehyde and EPON), Agar Scientific (saphranine), Aldrich $\left(\mathrm{Na}_{2} \mathrm{~S}\right)$, Pronalab (remaining liquid reagents) and Merck (remaining solid reagents).

\section{Results and discussion}

\section{Soil properties}

Properties of the soil collected at the banks of Esteiro de Estarreja are given in Table 1. The soil used in this study presented a $\mathrm{Zn}$ level of about $426 \mathrm{mg} \mathrm{Zn} \mathrm{kg}^{-1}$ dry soil. According to Kabata-Pendias and Pendias (1984), a total fraction of 70$400 \mathrm{mg} \mathrm{kg}^{-1} \mathrm{Zn}$ in the soil would already be considered as toxic to plants. In addition, the observed $\mathrm{Zn}$ level in the soil is slightly higher than what is set in legislation for agricultural soils, $150-300 \mathrm{mg} \mathrm{kg}^{-1}$, for soils with $\mathrm{pH}$ ranging from 6 to 7 (EC Directive 86/278/CEE from June 12th), and falls within the range of contamination seen as potential for the application of phytoremediation based clean-up strategies, as one of the disadvantages of the technique is the possible toxicity of high levels of metals present in the soil to plants (Glass, 2000). The metal phytoavailability - the fraction of the total contaminant mass in soil considered to be available for the receptor plant (Luthy et al., 2003)-has emerged as an important paradigm, replacing the old belief that biological response by receptor organisms could be predicted by the total concentration in the soil (Adriano et al., 2004). In general, aqueous extraction seems to provide an estimate of the amount of bioavailable metal in the soil solution. Estimates of the total bioavailable metal, which includes not only the metal available in soil solution but also the metal ions bound to soil exchange sites, are obtained by extracting the soil with organic compounds. In the present study, the $\mathrm{Zn}$ content extractable by water, ammonium acetate or EDTA represent 2, 4 or $28 \%$ of the total, respectively (Table 1). Therefore, in metal

Table 1

Soil properties

\begin{tabular}{|c|c|}
\hline $\mathrm{pH}$ & $6.24 \pm 0.03$ \\
\hline Water content $(\%)$ & $1.14 \pm 0.05$ \\
\hline Organic content $(\%)$ & $6.8 \pm 0.3$ \\
\hline $\mathrm{N}\left(\mathrm{mg} \mathrm{kg}^{-1}\right.$ soil) & $3960 \pm 129$ \\
\hline $\mathrm{P}\left(\mathrm{mg} \mathrm{kg}^{-1}\right.$ soil $)$ & $179 \pm 16$ \\
\hline Total $\mathrm{Zn}\left(\mathrm{mg} \mathrm{kg}^{-1}\right.$ soil $)$ & $426 \pm 2$ \\
\hline EDTA extractable $\mathrm{Zn}\left(\mathrm{mg} \mathrm{kg}^{-1}\right.$ soil) & $121 \pm 3$ \\
\hline $\mathrm{NH}_{4}$-Ac extractable $\mathrm{Zn}\left(\mathrm{mg} \mathrm{kg}^{-1}\right.$ soil $)$ & $15.3 \pm 0.7$ \\
\hline $\mathrm{H}_{2} \mathrm{O}$ extractable $\mathrm{Zn}\left(\mathrm{mg} \mathrm{kg}^{-1}\right.$ soil $)$ & $8.1 \pm 0.6$ \\
\hline
\end{tabular}

Results are expressed as means $\pm \mathrm{SD}(n=3)$. 
bioavailability investigations the use of different soil extraction techniques is recommended (Lasat, 2002). The non-acidic characteristics of the soil used in this study also indicate that the metal is not all readily available for plant uptake, as $\mathrm{Zn}$ solubility decreases with $\mathrm{pH}$ increase (Lucas and Davis, 1961).

The acid washed sand used as a control in the experiments was also tested for total, water, extractable and available $\mathrm{Zn}$ - using the same procedures described for the analysis of $\mathrm{Zn}$ contents in the soil-and no metal was detectable in either of the fractions.

\section{Mycorrhizal colonisation}

No AMF colonisation was found in the plants inoculated with a sterilised mixture (controls). Two-way ANOVA was performed for the dependent variable AMF colonisation versus the independent variables matrix (sand and contaminated soil) and inoculated fungi (Glomus sp. BEG140, Glomus claroideum, Glomus mosseae, Glomus intraradices and the mixture of all the AMF isolates) (Fig. 1). Soil contamination influenced $(P<0.05)$ positively mycorrhizal colonisation in $S$. nigrum and the AMF species only had a significant $(P<0.05)$ influence on the colonisation in the case of plants inoculated with $G$. intraradices-presenting significantly $(P<0.05)$ higher infection rates than the rest- and the mixture of all the fungipresenting the significantly $(P<0.05)$ highest colonisation rates of $S$. nigrum.

A positive relation between soil contamination and AMF presence has also been shown in other studies. Tonin et al. (2001) found that soil polluted with $\mathrm{Cd}$ and $\mathrm{Zn}$ enhanced the mycorrhizal colonisation of roots of Trifolium repens. Root colonisation of Zea mays was also found to be higher in a $\mathrm{Cd}, \mathrm{Cu}, \mathrm{Pb}$ and $\mathrm{Zn}$ polluted soil than in ancontaminated one (Weissenhorn et al., 1995). Whitfield et al. (2004) reported enhanced mycorrhizal colonisation of Thymus polytrichus when grown in $\mathrm{Cd}, \mathrm{Pb}$ and $\mathrm{Zn}$ enriched soil. In the present study, this positive relation may be due to the use of AMF

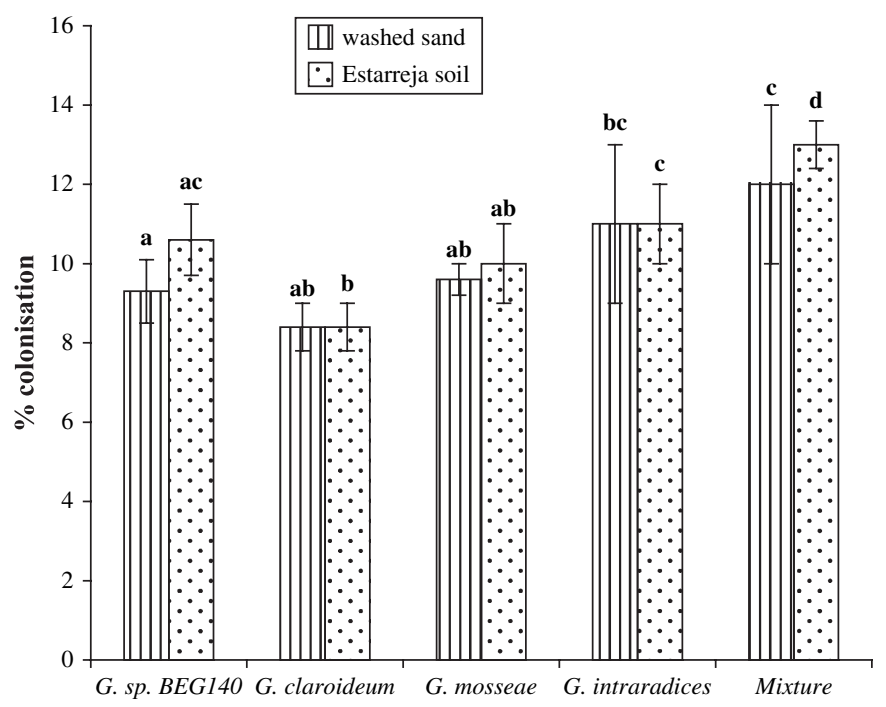

Fig. 1. Percentage of mycorrhizal colonisation (\%) for each treatment. Results are expressed as percentual means. The error bar represents the $\operatorname{SD}(n=6)$. isolates indigenous from metal contaminated sites, which can develop heavy metal tolerance by means of adaptation towards heavy metal contamination (Leung et al., 2006).

\section{Plant biomass}

Plants grown in contaminated soil had higher stem and lower root masses (Table 2). The higher nutrient content of the contaminated soil may explain higher stem biomasses but plant biomass reduction can be expected in plants in the presence of $\mathrm{Zn}$ (Kochian, 1993), especially in the case of the roots, as they are absorptive organs, and are thus subjected to earlier and higher accumulation (Xiong, 1998). MacFarlane and Burchett, (2002) also reported a reduction in the root biomass and an increase in the stem biomass of Avicennia marina plants exposed to $\mathrm{Zn}$.

It has been reported by many researchers that AMF colonisation reduces weight, branching, length, and fineness of roots (Hetrick et al., 1988; Koide, 1985; Price et al., 1989). This is possibly due to an AMF-mediated increase of $\mathrm{P}$ uptake. Since the plant is able to uptake more $\mathrm{P}$ only with the aid of AMF external hyphae, a greater area for nutrient absorption is not required, thus the root fresh and dry weights may be reduced (Smith and Read, 1997). However, in the present study, AMF colonisation did not influence the biomass yield of $S$. nigrum (Table 2), and few significant $(P>0.05)$ differences were found between the biomass of stems, roots or leaves of $S$. nigrum when inoculated with the different AMF species. Nevertheless, none of these treatments presented significant $(P<0.05)$ differences comparing with the non-inoculated control, suggesting that, in general, the presence of AMF did not influence the growth and biomass formation of S. nigrum individuals. Although the relationships between plants and AMF are generally reported as mutualistic (Smith and Read, 1997), neutral plant responses, as observed in this study, have been observed by other authors (Johnson et al., 1997).

\section{$\mathrm{Zn}$ concentration in the plant}

The matrix contamination had an influence in the $\mathrm{Zn}$ content in the tissues of S. nigrum, with the tissues of plants grown in contaminated soil always presenting higher Zn levels (Table 3). $S$. nigrum plants grown in the contaminated soil accumulated up to $1622 \mathrm{mg} \mathrm{kg}^{-1}$ of $\mathrm{Zn}$ in the roots, $411 \mathrm{mg} \mathrm{kg}^{-1}$ in the stems and $253 \mathrm{mg} \mathrm{kg}^{-1}$ in the leaves. The levels registered for the roots are considered as phytotoxic for plants-500$1500 \mathrm{mg} \mathrm{kg}^{-1}$, according to Chaney (1989) — but all the tissues showed $\mathrm{Zn}$ levels above what is considered as normal levels in plant tissues, $10-100 \mathrm{mg} \mathrm{kg}^{-1}$, according to Frisberg et al. (1996), independently of the inoculation with AMF.

As regards the leaf tissues, the AMF inoculated plants did not present significant $(P<0.05)$ differences from the nonmycorrhizal individuals in the case of control sand matrix. Plants grown in contaminated soil and germinated in a $G$. claroideum or $G$. intraradices inoculated matrix had significantly $(P<0.05)$ higher $\mathrm{Zn}$ accumulation in the leaf tissues than the ones with other or no AMF colonisation (Table 3). 
Table 2

Influence of different AMF species on Solanum nigrum biomass (g) grown in control and contaminated matrixes

\begin{tabular}{|c|c|c|c|c|c|c|}
\hline \multirow[t]{2}{*}{$\mathrm{AMF}$} & \multicolumn{3}{|l|}{ Control sand } & \multicolumn{3}{|l|}{ Contaminated soil } \\
\hline & Root & Stem & Leaves & Root & Stem & Leaves \\
\hline No fungi & $2.2430 \pm 1.0612(6)^{\mathrm{a}}$ & $3.4945 \pm 1.0194(6)^{\mathrm{ab}}$ & $1.5797 \pm 0.3195(6)^{\mathrm{a}}$ & $1.8328 \pm 0.1934(6)^{\mathrm{a}}$ & $8.4576 \pm 0.6972(4)^{\mathrm{a}}$ & $1.7949 \pm 0.4762(6)^{\mathrm{a}}$ \\
\hline $\begin{array}{r}\text { Glomus sp. } \\
\text { BEG140 }\end{array}$ & $2.0750 \pm 0.4300(6)^{\mathrm{a}}$ & $3.7018 \pm 1.4697(6)^{\mathrm{ab}}$ & $1.8966 \pm 0.6186(6)^{\mathrm{a}}$ & $1.8542 \pm 0.4604(6)^{\mathrm{a}}$ & $5.6559 \pm 1.3067(5)^{\mathrm{b}}$ & $1.5519 \pm 0.5587(6)^{\mathrm{a}}$ \\
\hline G. claroideum & $2.4744 \pm 0.6489(6)^{\mathrm{a}}$ & $4.3592 \pm 0.5679(6)^{\mathrm{b}}$ & $1.9261 \pm 0.4561(6)^{\mathrm{a}}$ & $1.9748 \pm 0.2625(4)^{\mathrm{a}}$ & $4.4544 \pm 0.6065(4)^{\mathrm{b}}$ & $1.4866 \pm 0.3446(6)^{\mathrm{a}}$ \\
\hline G. mosseae & $2.3532 \pm 0.9068(6)^{\mathrm{a}}$ & $2.2600 \pm 0.8803(5)^{\mathrm{a}}$ & $1.6061 \pm 0.4784(5)^{\mathrm{a}}$ & $1.8954 \pm 0.4786(6)^{\mathrm{a}}$ & $3.8577 \pm 0.7515(4)^{\mathrm{b}}$ & $1.8759 \pm 0.4797(6)^{\mathrm{a}}$ \\
\hline G. intraradices & $2.4075 \pm 0.7231(6)^{\mathrm{a}}$ & $4.7235 \pm 0.6276(6)^{\mathrm{b}}$ & $2.0368 \pm 0.3072(6)^{\mathrm{a}}$ & $1.8197 \pm 0.2458(4)^{\mathrm{a}}$ & $8.5712 \pm 0.5386(4)^{\mathrm{a}}$ & $1.6893 \pm 0.3904(6)^{\mathrm{a}}$ \\
\hline Mixture & $1.7915 \pm 0.5219(5)^{\mathrm{a}}$ & $3.7041 \pm 0.3130(5)^{\mathrm{ab}}$ & $1.6946 \pm 0.3476(5)^{\mathrm{a}}$ & $1.7942 \pm 0.1879(6)^{\mathrm{a}}$ & $8.2986 \pm 1.3144(4)^{\mathrm{a}}$ & $1.8044 \pm 0.3219(6)^{\mathrm{a}}$ \\
\hline
\end{tabular}

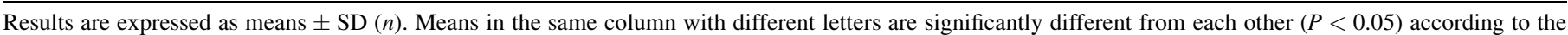
Tukey test.

S. nigrum individuals grown in soil collected from Estarreja and inoculated with AMF had a significantly $(P<0.05)$ higher $\mathrm{Zn}$ accumulation in the stems-except in the case of the AMF mixture inoculation-when comparing the non-inoculated plants. Plants inoculated with G. claroideum or G. intraradices presented significantly $(P<0.05)$ higher $\mathrm{Zn}$ levels in its stems (Table 3). These differences were not observed in plants grown in the control matrix.

For $\mathrm{Zn}$ accumulation in the roots, in the control sand, no significant $(P<0.05)$ difference was found with the AMF inoculations, but for the contaminated soil, plants inoculated with $G$. claroideum or $G$. intraradices presented significantly $(P<0.05)$ higher $\mathrm{Zn}$ accumulation in its tissue (Table 3$)$.

These results suggest that the inoculation with $G$. claroideum or $G$. intraradices led to higher $\mathrm{Zn}$ accumulation in the plant tissues, when germination and growth occurred in the Estarreja soil, a naturally $\mathrm{Zn}$ contaminated matrix. These two Glomus species induced similar $\mathrm{Zn}$ accumulation in S. nigrum, however plants inoculated with $G$. claroideum had significantly $(P<0.05)$ lower root colonisation. It seems, therefore, that $\mathrm{Zn}$ accumulation is not related to the percentage of root colonisation by AMF, which was also reported by Toller et al. (2005) for sorghum treated with different mycorrhizal consortia. When the same AMF treatments were tested in other experiments using $S$. nigrum growing in an artificially contaminated sand matrix, exposed to $\mathrm{Zn}$ levels up to $1000 \mathrm{mg} \mathrm{kg}^{-1}$ of dried sand, the inoculation with $G$. intraradices and $G$. claroideum also resulted in increased $\mathrm{Zn}$ accumulations in the tissues, up to $62 \%$ higher than those obtained for the non-inoculated individuals (Marques et al., in press).
A higher metal accumulation in AMF inoculated plants has been reported for other species. Mycorrhizal Trifolium repens and Zea mays growing in a $\mathrm{Zn}, \mathrm{Cu}, \mathrm{Cd}$ and $\mathrm{Pb}$ contaminated soil sequestrated more metals in the root and shoot compared to non-mycorrhizal plants (Joner and Leyval, 2001). Jamal et al. (2002) reported that AMF inoculation enhanced $\mathrm{Zn}$ accumulation in G. max and L. culinaris plants growing in a contaminated soil. Some reports even indicate higher concentrations of trace metals in plants due to AMF, resulting in levels that would usually be toxic to the plant (Joner and Leyval, 1997). One of the possible explanations for this increase in $\mathrm{Zn}$ accumulation in the mycorrhizal plants may be the stimulation caused by mycorrhization in the plant phenolic defence system resulting in the formation of thiols, like glutathione (Schützendubel and Andrea, 2002). This compound is structurally related to a form of peptides called phytochelatins. Such phytochelatins are able to bind heavy metals and detoxify contaminated soils (Cobbett and Goldsbrough, 2002), establishing higher uptake and accumulation in the plant. Higher phytochelatins levels can result in an increase in the accumulation of Zn (Faucheur et al., 2005). For all the AMF treatments the root tissues had, on average, the higher $\mathrm{Zn}$ content, followed by the stems, with the leaves registering the lowest values. This observation of the relative concentrations may suggest low translocation, which is contradicted when looking at absolute levels (accumulation $\times$ biomass), as the biomass of the aboveground part of the plants is always higher. A good candidate for a phytoextraction strategy would be a species that has a translocation factor higher than one (McGrath and Zhao, 2003). These absolute translocation rates

Table 3

Influence of different AMF species on Solanum nigrum Zn tissue concentration ( $\mathrm{mg} \mathrm{kg}^{-1}$ dry weight) grown in control and contaminated matrixes

\begin{tabular}{|c|c|c|c|c|c|c|}
\hline \multirow[t]{2}{*}{$\mathrm{AMF}$} & \multicolumn{3}{|l|}{ Control sand } & \multicolumn{3}{|l|}{ Contaminated soil } \\
\hline & Root & Stem & Leaves & Root & Stem & Leaves \\
\hline No fungi & $117 \pm 26(6)^{a}$ & $53 \pm 6(6)^{a}$ & $26 \pm 2(6)^{\mathrm{ab}}$ & $1029 \pm 64(6)^{\mathrm{a}}$ & $285 \pm 16(4)^{\mathrm{a}}$ & $114 \pm 16(6)^{a}$ \\
\hline Glomus sp. BEG140 & $139 \pm 22(6)^{a}$ & $57 \pm 10(6)^{\mathrm{a}}$ & $26 \pm 8(6)^{a b}$ & $1095 \pm 96(6)^{\mathrm{a}}$ & $363 \pm 11(5)^{\mathrm{bc}}$ & $131 \pm 20(6)^{a}$ \\
\hline G. claroideum & $110 \pm 8(6)^{\mathrm{a}}$ & $60 \pm 14(6)^{a}$ & $24 \pm 3(6)^{\mathrm{a}}$ & $1622 \pm 106(4)^{\mathrm{b}}$ & $411 \pm 30(4)^{\mathrm{d}}$ & $250 \pm 30(6)^{b}$ \\
\hline G. mosseae & $118 \pm 10(6)^{\mathrm{a}}$ & $53 \pm 11(5)^{\mathrm{a}}$ & $27 \pm 10(5)^{\mathrm{ab}}$ & $1027 \pm 102(6)^{\mathrm{c}}$ & $349 \pm 6(4)^{b}$ & $188 \pm 11(6)^{\mathrm{a}}$ \\
\hline G. intraradices & $144 \pm 14(6)^{\mathrm{a}}$ & $54 \pm 15(6)^{\mathrm{a}}$ & $28 \pm 2(6)^{b}$ & $1586 \pm 59(4)^{\mathrm{d}}$ & $397 \pm 14(4)^{\mathrm{cd}}$ & $253 \pm 19(6)^{b}$ \\
\hline Mixture & $126 \pm 7(5)^{a}$ & $54 \pm 4(5)^{a}$ & $25 \pm 5(5)^{\mathrm{ab}}$ & $1139 \pm 109(6)^{\mathrm{a}}$ & $251 \pm 11(4)^{\mathrm{e}}$ & $136 \pm 11(6)^{\mathrm{a}}$ \\
\hline
\end{tabular}

Results are expressed as means \pm SD $(n)$. Means in the same column with different letters are significantly different from each other $(P<0.05)$ according to the Tukey test. 

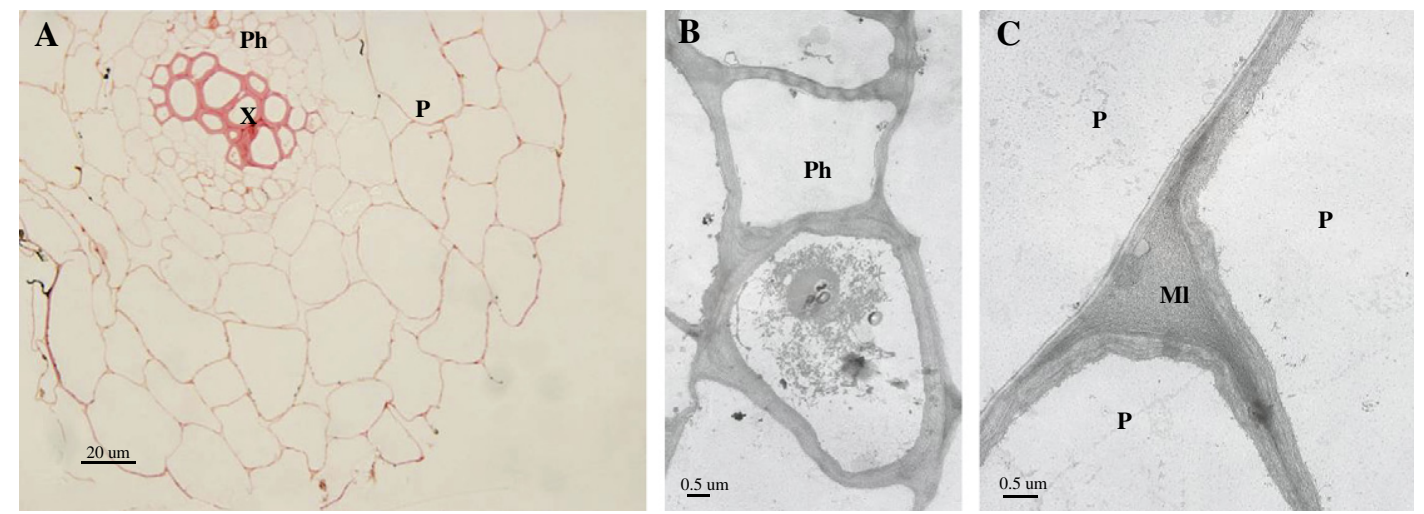

Fig. 2. Root section of Solanum nigrum inoculated with Glomus sp. BEG140 grown in control sand. After autometallography was performed on the root pieces, no labelling was detected in control plants. (A) General structure of the root as seen in cross section under the light microscope; cortical parenchyma cells (P), phloem $(\mathrm{Ph})$, xylem (X). (B) Electron microscopy image of a detail of the phloem cells (Ph). (C) Region of contact of three cortical parenchyma cells (P), middle lamellae (Ml).

of $S$. nigrum vary according to the growth matrix. When growth occurred in sand, the translocation rates were $0.86,0.90,1.13$, $0.59,0.90$ and 1.07 when the AMF treatment was, respectively, no fungi, Glomus sp. BEG140, G. claroideum, G. mosseae, $G$. intraradices and a mixture of all fungi. The rates obtained for plants grown in contaminated soil were generally higher then those registered for plants grown in the control sand, when the same AMF treatment was applied; 1.39, 1.11, 0.69, $0.87,1.33$ and 1.14 when the AMF treatment was, respectively, no fungi, Glomus sp. BEG140, G. claroideum, G. mosseae, $G$. intraradices and a mixture of all fungi. The application of AMF to plants grown in contaminated soil always resulted in a decrease of the translocation rate. This decrease may indicate that the tested AMF act as a zinc barrier in S. nigrum growing in a naturally contaminated matrix by immobilising heavy metals in the roots, restricting their translocation to stems (Kaldorf et al., 1999).

S. nigrum appears to have extracting and accumulating characteristics, according to the high $\mathrm{Zn}$ levels observed in its tissues when exposed to the $\mathrm{Zn}$ contamination of the substrate, with no apparent toxicity signs.

\section{Zn localisation}

Autometallography is a technique used to define the location of metals in the tissues and was first applied by Timm, 1958 (Heumann, 2002). The method has evolved and has become extremely specific for Zn ions (Ibata and Otsuka, 1969; Danscher and Zimmer, 1978). In environmental toxicology, autometallography has been used essentially as an option to observe the sites of metal accumulation in animal tissues (Soto et al., 1996). The application to plant tissues is scarce and until now few studies on the localisation of $\mathrm{Zn}$ have been reported, namely with the $\mathrm{Zn}$ tolerant species Armeria maritime (Heumann, 2002).

In the present study, autometallography was performed on root samples of all treatments. Figs. 2, 3 and 4 show representative results. Dark staining and electron-dense grains resulting from the metal presence are visible, especially on treatments resulting from plant growth on contaminated soil (Figs. 3 and 4), in comparison with root sections of $S$. nigrum plants grown in control sand (Fig. 2). This corroborates the data indicating that plants grown in a substrate rich in $\mathrm{Zn}$ accumulated higher
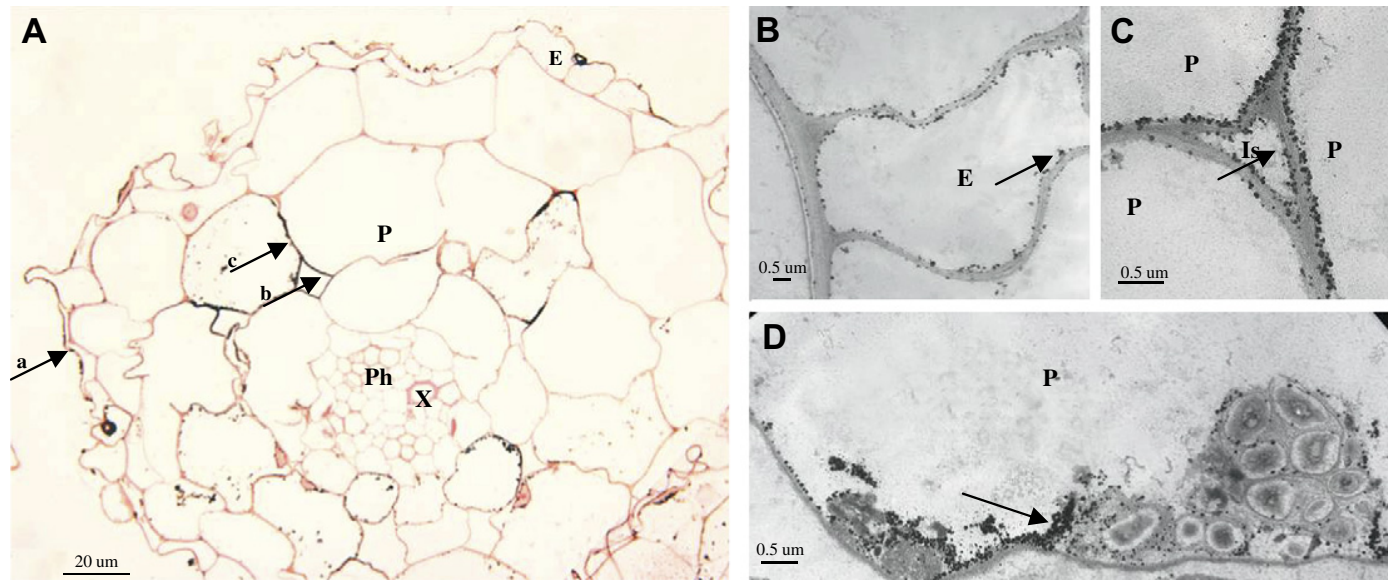

Fig. 3. Root sections of Solanum nigrum inoculated with Glomus sp. BEG140 grown in contaminated soil. (A) Light microscopy image of a root cross section; xylem $(\mathrm{X})$, phloem $(\mathrm{Ph})$, cortical parenchyma cells $(\mathrm{P})$ and the epidermal cells $(\mathrm{E})$. The arrows indicate $\mathrm{Zn}$ deposits, as revealed by the dark staining in the epidermis (a), the parenchyma cells of the cortex (c) and intercellular spaces (b). (B), (C) and (D) Electron microscopy analysis reveals Zn deposition (arrows) in the epidermal cells (E), in intercellular spaces (Is) and in the cytoplasm of cortical parenchyma cells (P). 

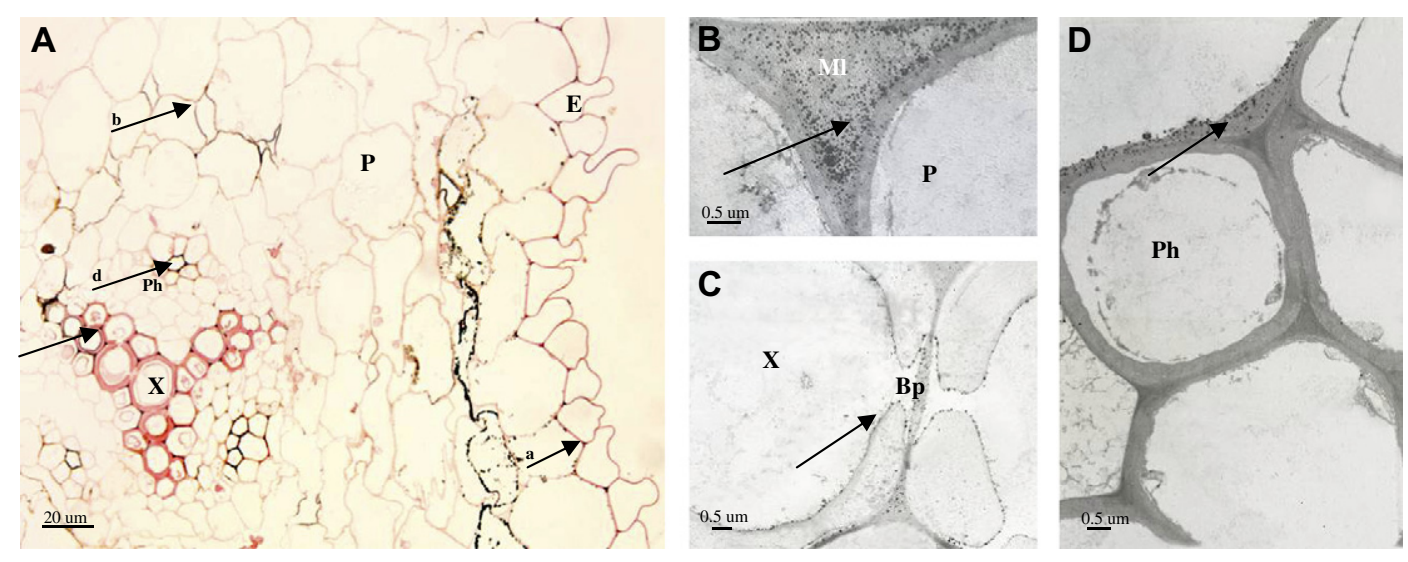

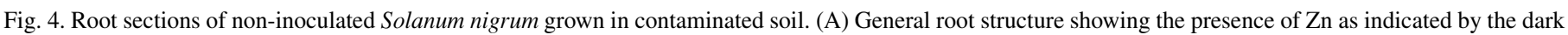

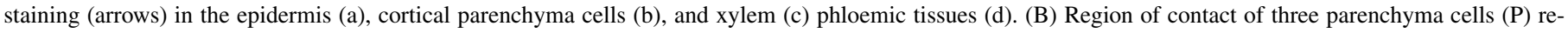

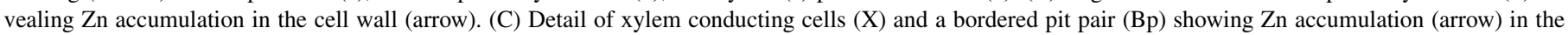
lumen of the cells adjacent to the cell walls. (D) Phloem parenchyma cells also reveal $\mathrm{Zn}$ deposits (arrow); phloem conducting element (Ph).

levels of the metal in its tissues than the plants grown in control sand. The deposits are present in the intercellular spaces and cell walls of the cortical parenchyma cells (Figs. 3C and 4B), and in the secondary cell wall of xylem conducting elements (Fig. 4C). Labelling was also found intracellularly (Fig. 3A), in particular in the epidermis (Fig. 3B), cortical parenchyma (Fig. 3D) and phloem cells (Fig. 4D). Similar localisation of metal accumulation has been found in the root tissues of $S$. nigrum plants growing in culture medium artificially contaminated with $\mathrm{Zn}$ - up to $100 \mathrm{mg} \mathrm{Zn}^{-1}$ (unpublished data). This is also consistent with reports found for other plants accumulating $\mathrm{Zn}$, as Thlaspi caerulescens (Frey et al., 2000), A. maritime ssp. halleri (Heumann, 2002), Silene vulgaris (Harmens et al., 1993) and Avicenia marina (MacFarlane and Burchett, 2002). According to Memon et al. (2001), $\mathrm{Zn}$ location at the cell wall level is one of the resistance mechanisms of tolerant plants, as it allows avoiding the $\mathrm{Zn}$ in the most sensitive areas, where the metabolic activities take place. The accumulation of $\mathrm{Zn}$ in the cellular walls and intercellular spaces was observed in plants for all the AMF treatments, as for the non-inoculated control.

The levels indicated as metal concentrations in the roots, as analysed via AAS, reflect metal absorbed within the root tissue and not metal just merely absorbed onto the root surface, as proposed by Weis and Weis (2004).

Autometallography was shown to be a good method for complementing studies on metal tissue accumulation brought by physical methods (atomic absorption spectroscopy after tissue acid digestion), allowing to localise the metals in the plant tissues, and contributing to the understanding of the mechanism through which $S$. nigrum avoids the $\mathrm{Zn}$ toxical effects in its roots.

\section{Conclusions}

The results obtained in our study suggest that, in the case of $S$. nigrum, the inoculation with G. claroideum and G. intraradices, resulted in higher $\mathrm{Zn}$ accumulation when the germination and growth was conducted in a $\mathrm{Zn}$ naturally contaminated soil. However, our data indicate that $\mathrm{Zn}$ uptake is not related to the percentage of root colonisation by AMF. The inoculation with $G$. claroideum induced an increase of 58, 44 and 120\% in the $\mathrm{Zn}$ accumulation levels for the roots, stems and leaves, respectively, when comparing to the noninoculated plants. When inoculated with $G$. intraradices, the increase in the accumulation levels was of 54, 39 and $122 \%$ for roots, stems and leaves, respectively. Nevertheless, in general, the presence of AMF did not influence the growth and biomass formation of $S$. nigrum.

As seen by electron microscopy, electron-dense grains resulting from the metal presence were visible in the intercellular spaces and in the cellular walls of root sections of $S$. nigrum plants grown on contaminated media, showing the apoplast as a $\mathrm{Zn}$ reservoir. The inoculation with different AMF species caused no differences in the localisation of $\mathrm{Zn}$ in the intercellular spaces and cell walls of $S$. nigrum roots.

The use of $S$. nigrum inoculated with $G$. claroideum or G. intraradices appears to be a good option for the decontamination of $\mathrm{Zn}$ contaminated soil due to the enhanced accumulating capacities presented by these associations.

\section{Acknowledgements}

The authors wish to thank Câmara Municipal de Estarreja for the provision of access to the site and Cláudia Pereira for help with sample fixation, autometallography and microscope observations. This work was supported by Fundação para a Ciência e a Tecnologia, research grants of Ana Marques (SFRH/BD/ 7030/2001) and Rui Oliveira (SFRH/BD/1464/2000). Miroslav Vosátka is acknowledged for providing the mycorrhizal fungi inocula. The work was funded by Project MICOMETA - POCI/ AMB/60131/2004 (Fundação para a Ciência e Tecnologia).

\section{References}

Adriano, D.C., Wenzel, W.W., Vangronsveld, J., Bolan, N.S., 2004. Role of assisted natural remediation in environment cleanup. Geoderma 122, 121-142. 
Atkins, W.S., 1999. Estratégia de Redução dos Impactes Ambientais Associados aos Resíduos Industriais Depositados no CQE. Estudo de Impacte Ambiental (Environmental Impact Study). IPAMB, Lisbon. No. 595.

Baker, A.M.J., McGrath, S.P., Reeves, R.D., Smith, J.A.C., 2000. Metal hyperaccumulator plants: a review of the ecology and physiology of a biochemical resource for phytoremediation of metal polluted soils. In: Terry, N., Banuelos, G. (Eds.), Phytoremediation of Contaminated Soil and Water. Lewis Publishers, pp. 85-107.

Borkert, C.M., Cox, F.R., Tucker, M.R., 1998. Zinc and copper toxicity in peanut, soybean, rice and corn in soil mixtures. Communications on Soil Science and Plant Analysis 29, 2991-3005.

Bürkert, B., Robson, A., 1994. ${ }^{65} \mathrm{Zn}$ uptake in subterraneum clover (Trifolium subterraneum $\mathrm{L}$.) by three vesicular arbuscular mycorrhizal fungi in a root free sandy soil. Soil Biology and Biochemistry 26, 1117-1124.

Bernhard, R., Verkleij, J.A.C., Nelissen, H.J.M., Vink, J.P.M., 2005. Plant specific responses to zinc contamination in a semi-field lysimeter and on hydroponics. Environmental Pollution 138, 100-108.

Cobbett, C., Goldsbrough, P., 2002. Phytochelatins and metallothioneins: roles in heavy metal detoxification and homeostasis. Annual Review of Plant Biology 54, 159-182.

Chaney, R.L., 1989. Toxic element accumulation in soils and crops: protecting soil fertility and agricultural food-chains. In: Bar-Yosef, B., Barrow, N.J., Goldshmid, J. (Eds.), Inorganic Contaminants in the Vadose Zone. Springer-Verlag, Berlin, pp. 140-158.

Danscher, G., Montagnese, C., 1994. Autometallographic localization of synaptic vesicular $\mathrm{Zn}$ and lysosomal gold, silver and mercury. Journal of Histotechnology $17,15-21$.

Danscher, G., Zimmer, J., 1978. An improved Timm sulphide silver method of light and electron microscopic localization of heavy metals in biological tissues. Histochemistry 55, 27-40.

De Koe, T., 1994. Agrostis castellana and Agrostis delicatula on heavy metal and arsenic enriched sites in NE Portugal. The Science of the Total Environment $145,103-109$.

Ebbs, S.D., Kochian, L.V., 1997. Toxicity of zinc and copper to Brassica species: implications for phytoremediation. Journal of Environmental Quality 26, 776-781.

Faucheur, S., Behra, R., Sigg, L., 2005. Thiol and metal contents in periphyton exposed to elevated copper and zinc concentrations: a field and microcosm study. Environmental Science and Technology 39, 8099-8107.

Frey, B., Keller, C., Zierold, K., Schulin, R., 2000. Distribution of Zn in functionally different leaf epidermal cells of the hyperaccumulator Thlaspi caerulescens. Plant. Cell and Environment 23, 675-687.

Frisberg, L., Nordberg, G.F., Kessler, E., Vouk, V.B., 1996. Handbook of the Toxicology of Metals, second ed., vols. I,II. Elsevier Science Publishers, Amsterdam.

Giovannetti, M., Mosse, B., 1980. An evaluation of techniques for measuring vesicular arbuscular mycorrhizal infection in roots. New Phytologist 84, 489-500.

Glass, D.J., 2000. Economic potential of phytoremediation. In: Raskin, I., Ensley, B.D. (Eds.), Phytoremediation of Toxic Metals: Using Plants to Clean Up the Environment. John Wiley \& Sons, Inc., pp. 18

Harmens, H., Gusmão, N.G.C.P.B., den Hartog, P.R., Verkleij, J.A.C., Ernst, W.H.O., 1993. Uptake and transport of $\mathrm{Zn}$ in $\mathrm{Zn}$ sensitive and $\mathrm{Zn}$ tolerant Silene vulgaris. Journal of Plant Physiology 141, 309-315.

Hetrick, B.A.D., Kitt, D.G., Wilson, G.W.T., 1988. Mycorrhizal dependence and growth habit of warm-season and cool-season tall grass prairie plants. Canadian Journal of Botany 66, 1376-1380.

Heumann, H.G., 2002. Ultrastructural localization of $\mathrm{Zn}$ in $\mathrm{Zn}$-tolerant Armeria maritime ssp. Halleri by autometallography. Journal of Plant Physiology 159, 191-203.

Hoagland, D.R., Arnon, D.I., 1950. The water-culture method for growing plants without soil. Circular 347. Agricultural Experiment Station. University of California, Berkeley.

Houba, V.J.G., van der Lee, J.J., Novozamsky, I., 1995. Soil Analysis Procedures. Department of Soil Science and Plant Nutrition. Wageningen Agricultural University, Syllabus, Wageningen.

Huang, Y., Chen, Y.J., Tao, C., 2002. Uptake and distribution of $\mathrm{Cu}, \mathrm{Zn}, \mathrm{Pb}$ and $\mathrm{Cd}$ in maize related to metals speciation changes in rhizosphere. Chinese Journal of Applied Ecology 13, 860-862.
Ibata, Y., Otsuka, N., 1969. Electron microscopic demonstration of $\mathrm{Zn}$ in the hippocampal formation using Timm's sulphide silver technique. Journal of Histochemistry and Cytochemistry 17, 171-175.

Jamal, A., Ayub, N., Usman, M., Khan, A.G., 2002. Arbuscular mycorrhizal fungi enhance $\mathrm{Zn}$ and nickel uptake from contaminated soil by soybean and lentil. International Journal of Phytoremediation 4, 205-221.

Johnson, N.C., Graham, J.H., Smith, F.A., 1997. Functioning of Mycorrhizal associations along the mutualism-parasitism continuum. New Phytologist $135,575-585$.

Joner, E.J., Leyval, C., 1997. Uptake of Cd by roots and hyphae of Glomus mosseae/Trifolium subterraneum mycorrhiza from soil amended with high and low concentration of cadmium. New Phytologist 135, 353-360.

Joner, E.J., Leyval, C., 2001. Time-course of heavy metal uptake in maize and clover as affected by root density and different mycorrhizal inoculation regimes. Biology and Fertility of Soils 33, 351-357.

Kabata-Pendias, A., Pendias, H., 1984. Trace Elements in Soils and Plants. CRC Press, Florida.

Kaldorf, M., Khun, A.J., Schröeder, W.H., Hildebrant, H., Bothe, H., 1999. Selective element deposits in maize colonised by a heavy metal tolerance conferring arbuscular mycorrhizal fungus. Journal of Plant Physiology $154,718-728$.

Khan, A.G., Chaudhry, T.M., Hayes, W.J., Khoo, C.S., Hill, L., Fernandez, R., Gallardo, P., 1998. Physical, chemical and biological characterization of a steelworks waste at Port Kembla, New South Wales, Australia. Water, Air and Soil Pollution 104, 389-402.

Kochian, L.V., 1993. Zinc absorption from hydroponic solutions by plant roots. In: Robson, A.D. (Ed.), Zinc in Soils and Plants. Kluwer Academic Publishers, Dordrecht, The Netherlands, pp. 45-57.

Koide, R.T., 1985. The nature of growth depressions in sunflower caused by vesicular arbuscular mycorrhizal infection. New Phytologist 99, 449-462.

Lasat, M.M., 2002. Phytoextraction of toxic metals: a review of biological mechanisms. Journal of Environmental Quality 31, 109-120.

Leung, H.M., Ye, Z.H., Wong, M.H., 2006. Interactions of mycorrhizal fungi with Pteris vittata (As hyperaccumulator) in As-contaminated soils. Environmental Pollution 139, 1-8.

Li, X.-L., Marschner, H., George, E., 1991. Acquisition of phosphorous and copper by V.A.-mycorrhizal hyphae and root-to-shoot transport in white clover. Plant and Soil 136, 49-57.

Lock, K., Janssens, F., Janssen, C.R., 2003. Effects of metal contamination on the activity and diversity of springtails in an ancient $\mathrm{Pb}-\mathrm{Zn}$ mining area at Plombiéres. Belgium. European Journal of Biology 39, 25-29.

Lucas, R.E., Davis, J.F., 1961. Relationships between $\mathrm{pH}$ values of organic soils and availabilities of 12 plant nutrients. Soil Science 92, 177-182.

Luthy, R.G., King, R.M.A., Brown, S.L., Dzomback, D.A., Fendorf, S.E., Giesy, J.P., Hughes, J.B., Luona, S.N., Malone, L.A., Menzie, C.A., Roberts, S.M., Ruby, M.V., Schulte, T.W., Smets, B.F., Ehlens, L.E., 2003. Bioavailability of contaminants in soils and sediments: processes, tools and applications. National Research Council, Committee on Bioavailability of Contaminants in Soils and Sediments. National Academy Press, Washington, DC.

Macek, T., Kotrba, P., Suchova, M., Skacel, F., Demnerova, K., Ruml, T., 1994. Accumulation of cadmium by hairy root cultures of Solanum nigrum. Biotechnology Letters 16, 621-624.

MacFarlane, G.R., Burchett, M.D., 2002. Toxicity, growth and accumulation relationships of copper, lead and $\mathrm{Zn}$ in the grey mangrove, Avicennia marina (Forsk.) Vierh. Marine Environmental Research 54, 65-84.

Marques, A.P.G.C., Oliveira, R.S., Rangel, A.O.S.S., Castro P.M.L. Zinc accumulation in Solanum nigrum is enhanced by different arbuscular mycorrhizal fungi. Chemosphere, in press.

Marques, A.P.G.C., Rangel, A.O.S.S., Castro, P.M.L., 2003. The uptake of heavy metals in plant species endemic to a polluted stream near an industrialized region of Portugal. In: Neves, M., Neves, A.C.V. (Eds.), Proceedings of the International Symposium Environment 2010-Situation and Perspectives for the European Union. Universidade do Porto, Faculdade de Engenharia, Porto, Portugal, pp. A01.

McGrath, S., Zhao, F.J., 2003. Phytoextraction of metals and metalloids from contaminated soils. Current Opinion in Biotechnology 14, 227-282. 
Memon, A.R., Aktoprakligil, D., Ozdemir, A., Vertii, A., 2001. Heavy metal accumulation and detoxification mechanisms in plants. Turkish Journal of Botany 25, 111-122.

Merharg, A.A., Cairney, J.W.G., 2000. Co-evolution of mycorrhizal symbionts and their hosts to metal-contaminated environments. Advances in Ecological Research 30, 69-112.

Oliveira, R.S., Dodd, J.C., Castro, P.M.L., 2001. The mycorrhizal status of Phragmites australis in several polluted soils and sediments of an industrialized region of Northern Portugal. Mycorrhiza 10, 241-247.

Phillips, J.M., Hayman, D.S., 1970. Improved procedures for clearing and staining parasitic and vesicular-arbuscular mycorrhizal fungi for rapid assessment of infection. Transcriptions of the British Mycology Society 55, $158-161$.

Price, N.S., Roncadori, R.W., Hussey, R.S., 1989. Cotton root growth as influenced by phosphorus nutrition and vesicular-arbuscular mycorrhiza. New Phytologist 111, 61-66.

Salema, R., Brandão, I., 1973. The use of PIPES buffer in the fixation of plant cells for electron microscope. Journal of Submicroscopic Cytology 5, 66-79.

Schützendubel, A., Andrea, P., 2002. Plant responses to abiotic stresses: heavy metal induced oxidative stress and protection by mycorrhization. Journal of Experimental Botany 53, 1351-1365.

Singh, O.V., Labana, S., Pandey, G., Budhirahja, R., 2003. Phytoremediation: an overview of metallic ion decontamination from soil. Applied Microbiology and Biotechnology 61, 405-412.

Smith, S.E., Read, D.J., 1997. Micorrhizal Symbiosis, second ed. Academic Press, London.

Soto, M., Cajaraville, M.P., Marigomez, I., 1996. Tissue and cell distribution of copper, zinc and cadmium in the mussed Mytilus galloprovinciallis, determined by autometallography. Tissue and Cell 28, 557-568.
Thomas, G.W., 1982. Exchangeable cations. In: Page, A.L., Miller, R.H., Keeney, D.R. (Eds.), Methods of Soil Analysis Part 2, Agronomy Series No.9. American Society of Agronomy and Soil Science. Soc. Am., Inc., Publishers, Madison, pp. 159-165.

Timm, F., 1958. Zur histochemie der schermetalle. Das sulphide-silberverfahren. Deutsche Zeitschrift für geriehtliche Medizin 46, 706-711.

Toller, H.D., Morton, J.B., Cumming, J.R., 2005. Growth and metal accumulation of mycorrhizal sorghum exposed to elevated copper and zinc. Water, Air, and Soil Pollution 164, 155-172.

Tonin, C., Vandenkoornhuyse, P., Joner, E.J., Straczeck, J., Leyval, C., 2001. Assessment of arbuscular mycorrhizal fungi diversity in the rhizosphere of Viola calaminaria and effect of these fungi on heavy metal uptake by clover. Mycorrhiza 10, 161-168.

Wallinga, I., Vark, W., Houba, V.J.G., Lee, J.J., 1989. Plant Analysis Procedures. Department of Soil Science and Plant Nutrition. Wageningen Agricultural University, Syllabus, Wageningen.

Weis, J.S., Weis, P., 2004. Metal uptake, transport and release by wetland plants: implications for phytoremediation and restoration. Environmental International 30, 685-700.

Weissenhorn, L., Leyval, C., Berthelin, J., 1995. Bioavailability of heavy metals and abundance of arbuscular mycorrhiza in soil polluted by atmospheric deposition from a smelter. Biology and Fertility of Soils 19, $22-28$.

Whitfield, L., Richards, A.J., Rimmer, D.L., 2004. Effects of mycorrhizal colonisation on Thymus polytrichus from heavy metal contaminated sites in northern England. Mycorrhiza 14, 47-54.

Xiong, Z.T., 1998. Lead uptake on seed germination and plant growth in a $\mathrm{Pb}$ hyperaccumulator Brassica pekinensis Rupr. Bulletin of Environmental Contamination and Toxicology 60, 285-291. 